\title{
EXPORT AND ECONOMIC GROWTH IN NAMIBIA: A GRANGER CAUSALITY ANALYSIS
}

\author{
ANDRE C. JORDAAN AND JOEL HINAUNYE EITA
}

\begin{abstract}
The purpose of this paper is to analyse the causality between exports and GDP of Namibia and to evaluate the relationship of these variables for the period 1970 to 2005. Time-series econometric techniques (Granger causality and cointegration) are applied to test the hypothesis of a growth strategy led by exports. It tests whether export Granger causes GDP, or whether the causality runs from GDP to exports, or if there is bi-directional causality between exports and GDP. The results revealed that exports Granger cause GDP and GDP per capita. This suggests that the export-led growth strategy through various incentives has a positive influence on growth.

Keywords: Exports, economic growth, causality, cointegration, error correction model
\end{abstract}

\section{INTRODUCTION}

The issue of how a country can achieve economic growth is one of the fundamental economic questions. An export-led growth hypothesis which states that exports are keys to promoting economic growth provides one of the answers to this fundamental question. There is a considerable literature that investigates the link and causation between exports and economic growth, but the conclusions still remain a subject of debate.

Exports are the most important source of foreign exchange, which can be used to ease pressure on the balance of payments and generate much-needed job opportunities. According to Abou-Stait (2005), an export-led growth strategy aims to provide producers incentives to export their goods through various governmental policies. The strategy also aims at increasing the capability of producing goods that can compete in the world market using advanced technology and make provision for foreign exchange needed to import capital goods. Exports can help the country to integrate in the world economy and help to reduce the impact of external shocks on the domestic economy. Exports allow domestic production to achieve a high level of economies of scale. Tsen (2006) stated that the experiences of East Asian economies provide good examples of the importance of the sector to economic growth and development, and this emphasises the role of exports as an engine for economic growth.

At independence in 1990, the new government of Namibia inherited an economy characterised by heavy dependence on the export of primary commodities (mainly minerals, fish and beef). Recognising the role of exports for the country to be competitive and have a sustainable level of growth, the government adopted an export-led growth strategy through value addition. One such example is the Export Processing Zone (EPZ) 
established in 1995 with the aim of encouraging export oriented manufacturing in order to increase employment and investment as well as the transfer of technology to the remainder of the economy (Bank of Namibia, 2002). Under the EPZ various incentives were offered to encourage exports. Although exports have been playing a role in the economic development of Namibia, there is no study testing the validity of the export-led growth hypothesis in Namibia. The objective of this paper is to investigate the impact of exports on the economic growth of Namibia for the period 1970-2005- It analyses the causality between exports and GDP of Namibia and evaluate the relationship of these variables. Time-series econometric techniques (Granger causality) will be applied to test the hypothesis of a growth strategy led by exports. It tests whether export Granger causes GDP, or whether the causality runs from GDP to exports, or if there is bi-directional causality between exports and GDP

Informal investigation of exports and GDP in Namibia shows that these two variables move together (see Fig. in the Appendix). It is generally accepted that countries which do well in their export performance also do well in their GDP performance and vice versa. This raises an important question on what the nature of this link is. It also raises an interesting issue on whether the co-movement between exports and GDP reflects only a growth accounting identity because exports is a component of GDP; or whether there is a causal relationship.

The paper is organised as follows. Section 2 provides an overview of the export-led growth strategy in Namibia; section 3 discusses the Granger causality methodology for exports and growth; section 4 discusses the empirical methodology, while section 5 and section 6 present the empirical results and conclusion.

\section{EXPORT-LED GROWTH STRATEGY IN NAMIBIA}

The Namibian government set up an EPZ in 1995- The aim of the EPZ is to attract investment that is geared towards the production of exports and the encouragement of transfer of skills and technology to Namibians (Shiimi, 2002). Following the success of Mauritius, several African countries (including Namibia) developed EPZs to promote exports. The Namibian EPZ offers incentives such as tax exemption, training incentives and protection from labour union pressures. Enterprises that manufacture for export, value-added processing in agro-industry and mineral beneficiation, storage and warehousing are eligible for the incentives. Other incentives for manufactures and exporters include exemption from import duties on imported intermediate and capital goods, and also from sales tax and transfer duties on goods and services that are required for EPZ activities.

Under the Export Development Strategy of 1998, processing of products from the primary sector such as marine-culture, agriculture and minerals were prioritised as subsectors for development. Although it focuses on Namibia's traditional primary exports, it is important to note that the country's comparative advantage lies in primary product processing. According to Jenkins (2002), this is the widest approach and should not mean that other sectors are ignored. However, Jenkins argues that insufficient attention is given to tourism, despite its potential in generating income.

The emphasis on exports is important for Namibia given the limited or small size of the domestic market. In any country, the development of the export sector starts with a readily available input supply which feeds into a developing manufacturing sector. 
As production becomes more competitive, an export market will develop. Jenkins (2002) suggests that linkages should be developed within an industry for businesses to be established at all levels.

\section{GRANGER CAUSALITY: EXPORT AND ECONOMIC GROWTH}

The Granger causality test was developed by Granger (1969) and, according to him, a variable (in this case exports) is said to Granger cause another variable (GDP) if past and present values of exports help to predict GDP. To test whether exports Granger cause GDP, this paper applies the causality test developed by Granger (1969). Asimple Granger causality test involving two variables, exports and GDP is written as:

$$
\begin{aligned}
& \text { Export }_{t}=\sum_{j=1}^{p} \alpha_{j} \text { Export }_{t-j}+\sum_{j=1}^{p} \beta_{j} G D P_{t-j}+u_{t} \\
& G D P_{t}=\sum_{j=1}^{p} \eta_{j} \text { Export }_{t-j}+\sum_{j=1}^{p} \gamma_{j} G D P_{t-j}+v_{t}
\end{aligned}
$$

The null hypotheses to be tested are:

$H_{1}: \eta_{j}=0, j=1 \ldots p$, which means that exports do not Granger cause GDP; and $H_{1}: \beta_{j}=0, j=1 \ldots p$, which means that GDP does not Granger cause exports. If none of the hypothesis is rejected, it means that exports do not Granger cause GDP and GDP also does not Granger cause exports. It indicates that the two variables are independent of each other. If the first hypothesis is rejected, it shows that exports Granger causes GDP. Rejection of the second hypothesis means that the causality runs from GDP to exports. If all hypotheses are rejected, there is bi-directional causality between exports and GDP.

The traditional Granger causality test uses the simple F-test statistics. Several studies such as Chow (1987), Marin (1992), Pomponio (1996), McCarville and Nnadozie (1995), Darat (1996) have used the traditional (F-test) to test for causality. The use of a simple traditional Granger causality has been identified by several studies (such as Engle and Granger, 1987; Toda and Yamamoto, 1995; Ahmad and Harnhirun, 1996; Zapata and Rambaldi, 1997; Shan and Tian, 1998; Tsen, 2006) as not sufficient if variables are 1(1) and cointegrated. If time series included in the analysis are 1(1) and cointegrated, the traditional Granger causality test should not be used, and proper statistical inference can be obtained by analysing the causality relationship on the basis of the error correction model (ECM). Many economic time-series are 1(1), and when they are cointegrated, the simple F-test statistic does not have a standard distribution. If the variables are 1(1) and cointegrated, Granger causality should be done in the ECM and expressed as:

$$
\begin{aligned}
& \Delta \text { Export }_{t-1}=\sum_{j=1}^{p} \alpha_{j} \Delta \text { Export }_{t-j}+\sum_{j=1}^{p} \beta_{j} \Delta G D P_{t-j}+\phi_{1} \varepsilon_{1 t-1}+u_{t} \\
& \Delta G D P_{t-1}=\sum_{j=1}^{p} \eta_{j} \Delta \text { Export }_{t-j}+\sum_{j=1}^{p} \gamma_{j} \Delta G D P_{t-j}+\phi_{2} \varepsilon_{2 t-1}+v_{t}
\end{aligned}
$$


where $\varepsilon_{1 t-1}$ and $\varepsilon_{2 \uparrow-2}$ are the lagged values of the error term from the following cointegration equations:

$$
\begin{aligned}
& \text { Export }_{t}=\delta+\varphi G D P_{t}+\varepsilon_{1 t} \\
& G D P_{t}=a+\psi \text { Export }_{t}+\varepsilon_{2 t}
\end{aligned}
$$

\section{EMPIRICAL METHODOLOGY}

Use of univariate characteristics that show whether the variables are stationary or nonstationary is the first step. If the variables are non-stationary their order of integration is tested. This paper uses the Augmented Dickey-Fuller (ADF) statistic to test the stationarity or non-stationarity of the variables and their order of integration. If the variables are 1(1), the next step is to test whether they are cointegrated. This is done by using the Johansen (1988, 1995) full information maximum likelihood. This econometric methodology corrects for autocorrelation and endogeneity parametrically using a vector error correction mechanism (VECM) specification. The Johansen procedure is described as follows. Defining a vector $x_{t}$ of $n$ potentially endogenous variables, it is possible to specify the data generating process and model $x_{t}$ as an unrestricted vector autoregression (VAR) involving up to $k$-lags of $x_{t}$ specified as:

$x_{t}=\mu+A_{1} x_{t-1}+\ldots+A_{k} x_{t-k}+\varepsilon_{t} \quad u_{t} \sim \operatorname{IN}\left(0, \sum\right)$,

where $x_{t}$ is $(n \times 1)$ and each of the $A_{t}$ is an $(n \times n)$ matrix of parameters. Sims (1980)

advocates this type of VAR modelling as a way of estimating dynamic relationships among jointly endogenous variables without imposing strong a priori restrictions (see also Harris, 1995). This is a system in reduced form and each variable in $x_{t}$ is regressed on the lagged values of itself and all the other variables in the system. Equation (7) can be re-specified into a vector error correction model (VECM) as:

$\Delta x_{t}=\mu+\Gamma_{1} \Delta x_{t-1}+\ldots+\Gamma_{k-1} \Delta x_{t-k+1}+\prod x_{t-k}+\varepsilon_{t}$

where $\Gamma_{i}=-\left(I-A_{1}-\ldots-A_{i}\right),(i=1, \ldots, k-1)$ and $\Pi=-\left(I-A_{i}-\ldots-A_{k}\right), I$ is a unit matrix, and $A_{i}(i=1, \ldots, p)$ are coefficient vectors, $p$ is the number of lags included in the system, $\varepsilon$ is the vector of residuals which represents the unexplained changes in the variables or influence of exogenous shocks. The $\bar{\Delta}$ represents variables in difference form which are $\mathrm{I}(0)$ and stationary and is $\mu$ a constant term. Harris (1995:77) states that this way of specifying the system has information on both the short and long-run adjustment to changes in $x_{t}$ through estimates of $\Gamma_{i}$ and $\Pi$ respectively. In the analysis of VAR, $\Pi$ is a vector which represents a matrix of long-run coefficients and it is of paramount interest. The long-run coefficients are defined as a multiple of two $(n \times r)$ vectors, and $\alpha$ and $\beta^{\prime}$, hence $\Pi=\alpha \beta^{\prime}$, where $\alpha$ is a vector of the loading matrices and denotes the speed of adjustment from disequilibrium, while $\beta^{\prime}$ is a matrix of long-run coefficients so that the term $\beta^{\prime} x_{t-1}$ in equation (8) represents up to $(n-1)$ cointegration relationships in the cointegration model. It is responsible for making sure that the $x_{t}$ converge to their long-run steady-state values. Evidence of the existence of cointegration is the same as evidence of the rank (r) for the $\Pi$ matrix. If it has a full rank, the rank $r=n$ and it is 
Table 1. ADF unit roots test

\begin{tabular}{lll}
\hline Variable & Test statistic Levels & First Difference \\
InExport & -3.079 & $-6.296^{* * *}$ \\
InGDP & -2.624 & $-3.915^{* *}$ \\
LnGDP per capita & -2.022 & $-3.728^{* *}$ \\
InImport & -2.982 & $-6.168^{* * *}$ \\
\hline
\end{tabular}

**/*** Indicates rejection of the null hypothesis of unit root at $5 \% / 1 \%$ significance level.

Table 2. Johansen cointegration test results: exports and GDP

\begin{tabular}{|c|c|c|c|c|}
\hline Null hypothesis & Alternative hypothesis & Test statistic & 0.05 critical value & Probability value $^{b}$ \\
\hline $\begin{array}{l}\text { Trace statistic } \\
\mathrm{r}=0 \\
\mathrm{r}=1\end{array}$ & $\begin{array}{l}r=1 \\
r=2\end{array}$ & $\begin{array}{c}27.583^{a} \\
6.829\end{array}$ & $\begin{array}{r}20.262 \\
9.165\end{array}$ & $\begin{array}{l}0.004 \\
0.136\end{array}$ \\
\hline $\begin{array}{l}\text { Maximum eigenv } \\
r=0 \\
r \leq 1\end{array}$ & $\begin{array}{l}\text { tic } \\
r>0 \\
r>1\end{array}$ & $\begin{array}{c}20.754^{a} \\
6.829 \\
\end{array}$ & $\begin{array}{r}15.892 \\
9.165 \\
\end{array}$ & $\begin{array}{l}0.007 \\
0.136 \\
\end{array}$ \\
\hline
\end{tabular}

${ }^{2}$ Denotes rejection of the null hypothesis at 0.05 level.

${ }^{b}$ MacKinnon-Haug-Michelis (1999) p-values.

said that there are $n$ cointegrating relationships and that all variable are $I(0)$. If it is assumed that $x_{t}$ is a vector of nonstationary variables $I(1)$, then all terms in equation (8) which involves $\Delta x_{t-i}$ are $I(0)$, and $\Pi x_{t-k}$ must also be stationary for $\varepsilon_{t} \sim I(0)$ to be white noise. The cointegrating rank is tested with two statistics, the trace and maximum eigenvalue.

If there is cointegration, it shows evidence of a long-run relationship between the variables and appropriateness of proceeding to test the direction of causality as illustrated in equations (3) and (4).

\section{EMPIRICAL RESULTS}

Univariate Characteristics of the Variables

The variables are tested for stationarity using the ADF test statistic. The results are presented in Table 1.

The results of Table 1 show that all variables are non-stationary in levels, but stationary in first difference. Since the variables are 1(1) the next step is to test if they are cointegrated using the Johansen full information maximum likelihood. The lag length for all estimations was based on the Akaike information criterion, Log likelihood ratio, Final prediction error, Schwarz information criteria, and Hannan-Quinn information criterion The results of cointegration test are presented in Tables $2-4$.

Tables 2 and 3 show that there is one cointegration vector between exports and GDP as well as between exports and GDP per capita. Some studies such as Riezman and Whiteman (1996), and Shan and Sun (1999) established that standard methods of testing the export-led growth hypothesis using Granger causality test may give misleading results if imports are not included in the equation. This paper acknowledges the latter and includes imports in the analysis. The cointegration results between exports, imports and GDP per capita are presented in Table 4 . The results show that there are two cointegrating vectors between the three variables. 
Table 3. Johansen cointegration test results: exports and GDP per capita

\begin{tabular}{lcccc}
\hline $\begin{array}{l}\text { Null hypothesis } \\
\text { Trace statistic }\end{array}$ & Alternative hypothesis & Test statistic & $\mathbf{0 . 0 5}$ critical value & Probability value $^{\mathbf{b}}$ \\
$\mathrm{r}=0$ & $\mathrm{r}=1$ & $19.287^{2}$ & 18.397 & 0.038 \\
$\mathrm{r}=1$ & $\mathrm{r}=2$ & 2.165 & 3.841 & 0.141 \\
Maximum eigenvalue statistic & & & 0.0504 \\
$\mathrm{r}=0$ & $\mathrm{r}>0$ & 17.122 & 17.148 & 0.141 \\
$\mathrm{r} \leq 1$ & $\mathrm{r}>1$ & 2.165 & 3.841 & \\
\hline
\end{tabular}

a Denotes rejection of the null hypothesis at 0.05 level.

b MacKinnon-Haug-Michelis (1999) p-values.

Table 4. Johansen cointegration test results: exports, imports and GDP per capita

\begin{tabular}{|c|c|c|c|c|}
\hline Null hypothesis & Alternative hypothesis & Test statistic & 0.05 critical value & Probability value $e^{b}$ \\
\hline $\begin{array}{l}\text { Trace statistic } \\
\mathrm{r}=0 \\
\mathrm{r}=1 \\
\mathrm{r}=2\end{array}$ & $\begin{array}{l}r=1 \\
r=2 \\
r=3\end{array}$ & $\begin{array}{c}46.567^{a} \\
22.329^{2} \\
2.753\end{array}$ & $\begin{array}{r}35.193 \\
20.262 \\
9.165\end{array}$ & $\begin{array}{l}0.002 \\
0.026 \\
0.628\end{array}$ \\
\hline $\begin{array}{l}\text { Maximum eigenva } \\
r=0 \\
r \leq 1 \\
r \leq 2\end{array}$ & $\begin{array}{l}r \\
r>0 \\
r>1 \\
r>2\end{array}$ & $\begin{array}{c}24.237^{a} \\
19.577^{2} \\
2.753\end{array}$ & $\begin{array}{r}22.299 \\
15.892 \\
9.165\end{array}$ & $\begin{array}{l}0.027 \\
0.013 \\
0.628\end{array}$ \\
\hline
\end{tabular}

${ }^{a}$ Denotes rejection of the null hypothesis at 0.05 level.

${ }^{b}$ MacKinnon-Haug-Michelis (1999) p-values.

Table 5. Results of Granger causality

\begin{tabular}{lll}
\hline $\mathbf{H}_{0}$ & Wald statistic & Probability \\
Export and GDP & & \\
Export does not cause GDP & $4.0121^{*}$ & 0.045 \\
GDP does not cause export & 0.038 & 0.849 \\
Export and GDP per capita & & \\
Export does not cause GDP per capita & $4.054^{*}$ & 0.044 \\
GDP per capita does not cause export & 0.401 & 0.562 \\
Export, import and GDP per capita & & \\
Import does not cause export & $8.380^{*}$ & 0.004 \\
Export does not cause import & $7.460^{*}$ & 0.006 \\
Export does not cause GDP per capita & $3.319^{*}$ & 0.069 \\
Import does not cause GDP per capita & 0.365 & 0.546 \\
\hline
\end{tabular}

* Indicates rejection of the null hypothesis.

Granger Causality Results

Since there is cointegration between the variables, the final step is to test for the direction of causality using the vector error correction model. The presence of a cointegrating vector allows for the use of a vector error correction model to test causality. The results of the Granger causality test are presented in Table 5-

Table 5 shows that the export led growth hypothesis is supported by the data. It is shown that exports Granger causes GDP and GDP per capita. Imports were also included in the analysis to test the significance of imports in driving economic growth in Namibia. The results show that there is bi-directional causality between exports and imports, but imports do not Granger cause GDP per capita. Although not shown here, the coefficient of the lagged error correction term for all models is negative and significant and this implies that there is a long-run causal relationship between exports and economic growth in Namibia. These results provide evidence that growth in Namibia was propelled by an export-led growth strategy. Exports are thus seen as the source of economic growth in Namibia. 


\section{CONCLUSION}

The purpose of this paper was to test if the export-led growth strategy is supported by data in Namibia. The analysis covers the period 1970 to 2005, including several years even before the adoption of the export-led growth strategy in 1995- A Granger causality test on the basis of the error correction model was used to test the causality between exports, GDP and GDP per capita, as well as between exports, imports and GDP per capita. The paper tested whether exports and GDP or GDP per capita are cointegrated. It also tested if exports, imports and GDP are cointegrated. The test results revealed evidence of cointegration between exports and GDP or GDP per capita. It also revealed that exports, imports and GDP per capita are cointegrated. A granger causality analysis was carried out and the results provided evidence of causality running from exports to GDP or GDP per capita. The results also show that there is bi-directional causality between exports and imports. However, imports do not Granger cause GDP per capita.

The results suggest that an export-led growth strategy through offering various incentives has paid off and a long-term relationship between exports and GDP has emerged. Export promotion has a positive influence on growth in GDP. The results confirm further the advantages of an export-led growth strategy for Namibia. Namibia can expand its limited domestic market by exporting products to the international markets. Policies focusing on export promotion should be used effectively to build export capacity in order to increase economic growth.

\section{APPENDIX: VARIABLES USED IN THE ESTIMATION}
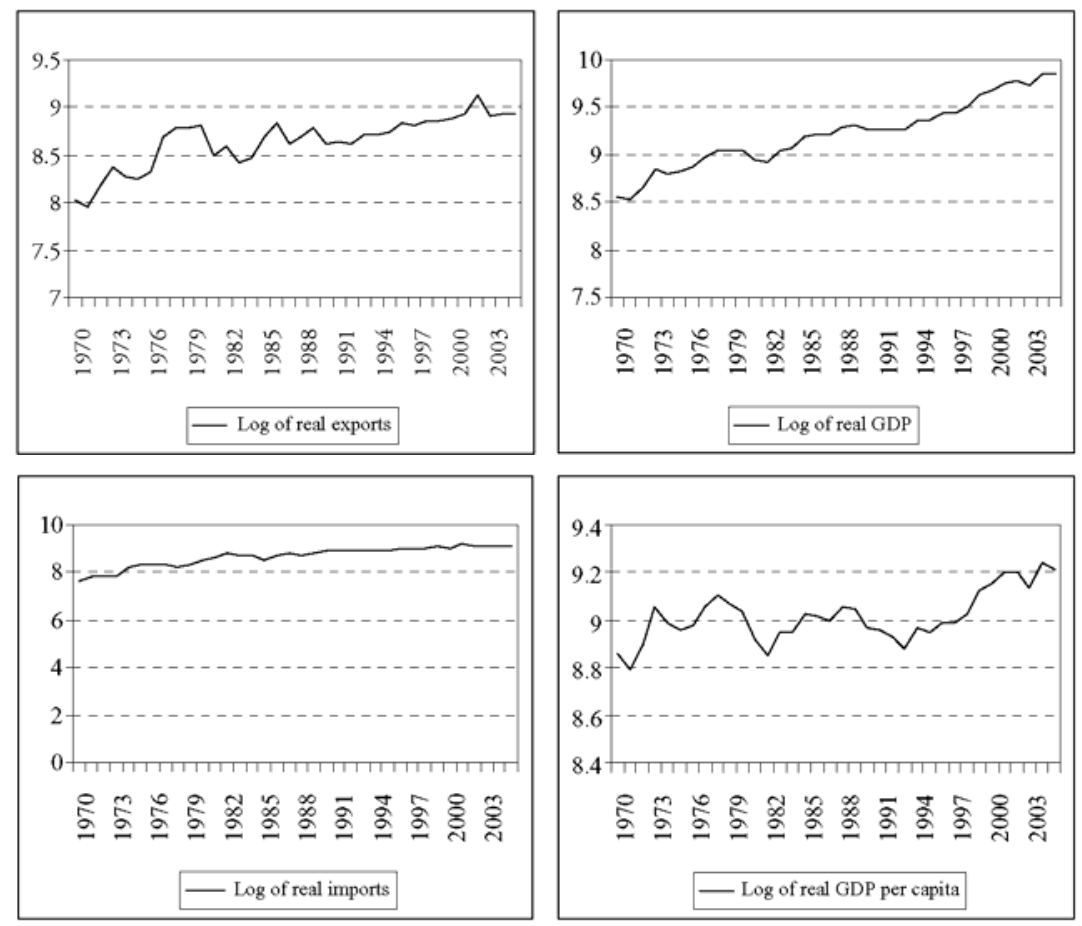

Figure 1. Variables used in the estimation 


\section{REFERENCES}

ABOU-STAIT, R (2005). Are exports the engine of economic growth? An application of cointegration and causality analysis for Egypt, 1977-2003. Economic Research Working Paper Series. Tunis: African Development Bank.

AHMAD, J. and HARNHIRUN, S. (1996). Cointegration and causality between exports and economic growth: Evidence from the ASEAN countries. The Canadian Journal of Economics, 29 (Special issue, part 2): S413-S416.

BANK OF NAMIBIA. (2002). Annual Report. Windhoek: Bank of Namibia.

CHOW, P. C. Y. (1987). Causality between export growth and industrial development: Empirical evidence from the NICs. Journal of Development Economics, 26(1): 55-63.

DARAT, A. E (1996). Trade and development: The Asian experience. Cato Journal, 6(2): 695-699.

ENGLE, R. E and GRANGER, C. W J. (1987). Co-integration and error correction: Representation, estimation and testing. Econometrica, 55(2): 251-276

GRANGER, C. W J. (1969). Investigating the causal relations by econometric models and cross-spectral methods. Econometrica, 37(3): 424-438.

HARRIS, R. I. D. (1995). Using Cointegration Analysis in Econometric Modelling. London: Prentice Hall/Harvester Wheatsheaf.

JENKINS, C. (2002). Industrial policy, trade strategy and growth in Namibia. Paper Presented at the Bank of Namibia Annual Symposium, Windhoek Country Club and Casino - Windhoek, 7 August.

JOHANSEN, S. (1988). Statistical analysis of cointegrating vectors. Journal of Economic Dynamic and Control, 12 : 231-254.

--(1995). Likelihood Based Inferences in Cointegrated Vector Autoregressive Models. Oxford: Oxford University Press. MARIN, D. (1992). Is the export-led growth hypothesis valid for industrialised countries? Review of Economics and Statistics, 74(4): 678-688.

MCCARVILLE, M. and NNADOZIE, E. (1995). Causality test of export-led growth: The case of Mexico. Atlantic

Economic Journal, 23(2): 140-145.

POMPONIO, X. Z. (1996). A causality analysis of growth and export performance. Atlantic Economic Journal, 24(2):

168-176.

RIEZMAN, R. G. and WHITEMAN, C. H. (1996). The engine of growth of its handmaiden? A time-series assessment of export-led growth. Empirical Economics, 21: 77-110.

SHAN, J. and TIAN, G. G. (1998). Causality between exports and economic growth: The empirical evidence from Shanghai. Australian Economic Papers, 37(2): 195-202.

SHIIMI, I. W (2002). An overview of Namibia's investment and growth performance, 1990-2001. Paper Presented at the Bank of Namibia Annual Symposium, Windhoek Country Club \& Casino — Windhoek, 7 August.

SIMS, C. (1980). Macroeconomics and reality. Econometrica, 48: 1-48.

SUN, E and SHAN, J. (1999). Export-led growth and the US economy: Another look. Applied Economic Letters, 3: 341-344.

TODA, H. Y. and YAMAMOTO, T (1995). Statistical inference in vector autoregressions with possibly integrated 'processes. Journal of Econometrics, 66: 225-250.

TSEN, W H. (2006). Granger causality tests among openness to international trade, human capital accumulation and economic growth in China: 1952-1999. International Economic Journal, 20(3): 285-302.

ZAPATA, H. O. and RAMBALDI, A. N. (1997). Monte Carlo evidence on cointegration and causation. Oxford Bulletin of Economics and Statistics, 59(2): 285-298. 